\title{
Sentiency, bioethics and animal welfare: concepts that need to be discussed in higher education to change the teaching and researching paradigm
}

\section{Senciência, bioética e bem estar animal: conceitos que necessitam ser discutidos no ensino superior para mudar o paradigma na forma de ensinar e pesquisar}

\author{
Anderson do Prado Duzanski ${ }^{1}$; Ana Paula Millet Evangelista dos Santos ${ }^{2 *}$; \\ Mariza Fordellone Rosa $\mathrm{Cruz}^{2}$; Emília de Paiva Porto ${ }^{2}$; \\ Petrônio Pinheiro Porto ${ }^{2}$; Marcos Augusto Alves da Silva²; \\ Ellen de Souza Marquez²; Carlos Frederico Gitsio Klier Teixeira da Silva²
}

\begin{abstract}
This study investigated the knowledge of students of Veterinary Medicine and Biological Sciences of the State University of Northern Paraná, Campus Luiz Meneghel, on the ethical and legal guidelines of animal experimentation, as well as the possibility of substitute methods for using sentient animals in classes and scientific practices. The research involved 162 freshman students and graduating students, aged 17 to 32 years. The students responded to the questionnaire containing objective and subjective questions, and the answers were analysed by descriptive statistics. It was observed that $87 \%$ of the students were unaware of the concept of the " $3 \mathrm{Rs}$ " and $81.5 \%$ did not know the existence of alternative methods that can replace the use of live animals in studies. In addition, only $24.7 \%$ of respondents reported they had studied "bioethics" before graduation. However, $94.3 \%$ and $96.2 \%$ of the students from veterinary medicine and biological sciences, respectively, considered it important to insert animal welfare and bioethics in the curriculum of such courses. The results demonstrated that the ethical and statutory guidelines that rule the use of animals in scientific experiments and in classes are unknown even among senior students and there is still great resistance to the exclusion of animal models. Thus, it is important that animal welfare and bioethics remain in the curriculum in higher education through the insertion of such subjects, even as elective courses that aim to work with methodologies and innovative strategies in synergistic action with ethics committees for animal use, which are responsible for analysing, guiding and supervising the relevance of animal use in education and research. Therefore, the curriculum will be able to achieve rationalization in the use of animal models, the sustainable and "humanitarian" development of teaching and research, and the training of more conscious and ethical professionals, perceptions that must be achieved through a national education curriculum.
\end{abstract}

Key words: Animal welfare, animal ethics, animal experimentation, 3Rs, alternative methods

1 Discente do Curso de Graduação em Medicina Veterinária, da Universidade Estadual do Norte do Paraná, UENP, Bandeirantes, PR, Brasil. E-mail: andersonduzanski@hotmail.com

2 Profs., UENP, Centro de Ciências Agrárias, Setor de Veterinária e Produção Animal, Campus Luiz Meneghel, Bandeirantes, PR, Brasil. E-mail: apmillet@uenp.edu.br; mfordellone@uenp.edu.br; emilia@uenp.edu.br; petronio@uenp.edu.br; marcossilva@ uenp.edu.br; esmarquez@uenp.edu.br; fred.klier@uenp.edu.br

* Author for correspondence 


\section{Resumo}

Este trabalho investigou o conhecimento dos estudantes de Medicina Veterinária e de Ciências Biológicas, da Universidade Estadual do Norte do Paraná - Campus Luiz Meneghel, sobre as diretrizes éticas e legais da experimentação animal, bem como a possibilidade de substituição dos animais sencientes no ensino e na pesquisa. Foram entrevistados 162 discentes, dentre os quais ingressantes e concluintes dos referidos cursos, com idade entre 17 e 32 anos. No final do período letivo, concluindo as disciplinas curriculares do primeiro ou do último ano, os discentes responderam a perguntas objetivas e subjetivas, que foram analisadas por estatística descritiva. Observou-se que aproximadamente $87 \%$ dos discentes desconheciam os conceitos dos " 3 Rs" e que $81,5 \%$ desconheciam métodos alternativos que poderiam substituir o uso de animais vivos em estudos; apenas $24,7 \%$ afirmaram ter estudado bioética ao longo da graduação. Contudo, 94,3\% e 96,2\% dos discentes, respectivamente, de Medicina Veterinária e de Ciências Biológicas consideraram importante a oferta periódica de disciplina optativa que abordasse o bem estar animal e a bioética. Os resultados demonstraram, inclusive dentre os formandos, desconhecimento das diretrizes éticas e legais que norteiam o uso do animal em experimentos didáticocientíficos e que ainda há grande resistência na substituição de modelos animais. Assim, no ensino superior é importante manter na grade curricular, mesmo que de forma optativa, disciplina que aborde a bioética e o bem-estar animal e que propicie ampla discussão e reflexão sobre o tema. Além disso, não menos importante, é necessário maior envolvimento dos docentes, abordando o assunto em todas as disciplinas do curso, quando for oportuno. Com isto, esperar-se-á maior racionalização dos modelos animais, tanto no ensino quanto na pesquisa e maior conhecimento por parte dos discentes, quer sejam calouros ou formandos. Desta forma, o desenvolvimento sustentável e humanitário do ensino superior poderá refletir na formação de profissionais mais conscientes e éticos, perspectivas estas que devem ser tidas como meta na educação nacional.

Palavras-chave: Bem-estar animal, bioética animal, experimentação animal, 3Rs, métodos alternativos

In 1959, Russell and Burch published the book The Principles of Humane Experimental Technique, establishing the "3Rs" (Replacement, Reduction and Refinement) to rationalize animal use in scientific experimentation proposals (1) replacement of animal models for alternative models; (2) reduction of the number of animals in most experiments or studies; and (3) the technique of refinement in order to minimize the pain, discomfort or stress on the animals involved.

In higher education, most of the time the animal model is used as a tool that aims to deepen theoretical and practical learning and stimulate student interest in research. However, there are alternative methods for certain teaching practices that meet the principles of the " 3 Rs" and harmonize the process of teaching and learning, arousing moral reflections that can oppose unethical deformity and the virtue of ethics (KNIGHT, 2008).

In Brazil there are some important norms related to practices with animals. The Federal Law 9.605 (BRASIL, 1998) addresses environmental crimes and crimes against wildlife (wild, domestic, domesticated, native, or exotic), imposing penalties on those who perform painful or cruel experiments on live animals, even for educational or scientific purposes, when there are alternative resources. Federal Law 11.794 (BRASIL, 2008) regulates the legal criteria for animal experimentation in teaching and research and Decree 6.899 (BRASIL, 2009) establishes the National Council for Animal Experiments Control (CONCEA, in Portuguese), which aims to oversee and guide animal procedures in scientific activities, establishing the mandatory constitution of the Ethics Committee on Animal Use (CEUAs, in Portuguese) responsible for validating procedures with animals.

In this context, this study aims to determine the perception of freshmen and senior students in veterinary medicine and biological sciences at the Northern State University of Paraná, Campus Luiz Meneghel (UENP-CLM, in Portuguese) on the ethical and legal guidelines for the use of animals in teaching and research in light of Law 11.794/08. 
This is necessary as higher education institutions' endeavour to form critical, ethical, competent, and humanist professionals, committed to the society in which they live and to meet the demand for animal welfare.

One hundred and sixty-two students were interviewed voluntarily and anonymously at UENPCLM, of which 89 belonged to the veterinary medicine course (45 freshman and 44 seniors) and 73 to biological sciences (40 freshman and 33 seniors). At the end of the school year, after completing the curriculum subjects of the first or the last year, students answered the objective and subjective questions, which were analysed by descriptive statistics with an emphasis on the distribution of relative frequencies of responses.

It was found that $71 \%(115 / 162)$ of the respondents at UENP-CLM were female. In similar studies Feijó et al. (2008) reported that $69.3 \%$ of students surveyed in health area courses and in the life sciences at Pontifical Catholic University of Rio Grande do Sul (PUCRS, in Portuguese) also were female. At the Federal University of Rio Grande do Sul (UFRGS), $69.6 \%$ of the 102 medicine and biological sciences students interviewed by Danielski et al. (2011) were women. In the case of bioethics and of animal welfare it is expected that females show a higher sensitivity and concern about the use of the animal model for education and research. However, the results do not correspond to this expectation, probably due to ignorance of the subject.

Approximately $87 \%(140 / 162)$ of respondents were unaware of the "3Rs". This was observed in $86.6 \%(39 / 45)$ of freshmen and $81.8 \%(36 / 44)$ of senior students of veterinary medicine, and in $85 \%(34 / 40)$ of freshmen and $93.9 \%(31 / 33)$ of senior students of biological sciences. These results suggest that the principle of " $3 \mathrm{R}$ " has not been effectively addressed, or applied before graduation.

When asked about the use of animals in the proposed activities of teaching and research, it was observed that $31.1 \%(14 / 45)$ of freshmen and $100 \%$ $(44 / 44)$ of senior students of veterinary medicine and $10 \%(04 / 40)$ of freshmen and $42.4 \%(14 / 33)$ of senior students of biological sciences had studied with live animal models. At PUC, among freshmen students interviewed by Feijó et al. (2008), 98.6\% of the medical school, $41.7 \%$ of pharmacy, $23.3 \%$ of nutrition, $24.3 \%$ of nursing, $37.2 \%$ of dentistry, $44.7 \%$ of physical therapy, $100 \%$ of physical education, and $23.7 \%$ of biological sciences also claimed to have used animals in academic activities. Similar finding was verified by Danielski et al. (2011) for $96 \%$ of students of medicine and $80.7 \%$ of students of biological sciences at UFRGS. These results demonstrate that the animal model is still widely used in academia.

Among the respondents at UENP-CLM, 81.5\% $(132 / 162)$ considered the use of animals in academic activities (teaching and research) important, even if there is an ethical model. This perception was observed in $93.3 \%(42 / 45)$ of freshmen and $95.4 \%$ $(42 / 44)$ of senior students of veterinary medicine, and in $65 \%(26 / 40)$ of freshmen and $66.6 \%(22 / 33)$ of senior students of biological sciences on the grounds that it would be methodologically necessary for the transmission of information and realization of the proposed pedagogical idea and for the qualification of professional practice. According to Lima et al. (2008), such a perception was observed in only $38.5 \%$ of graduates in biological sciences, Federal University of Pernambuco (UFPE, in Portuguese) who believed that "alternative" methods would not always be sufficient to promote learning.

At UFRGS, $96 \%$ of students of medicine and $57.7 \%$ of biological sciences considered the use animals in education important. In addition, 96\% of students of medicine and $44.2 \%$ of biological sciences also considered studies with animals essential to the progress of biomedical knowledge (DANIELSKI et al., 2011).

Approximately $81.5 \%(131 / 162)$ of students were unaware of the existence of alternative or substitute methods to the use of live animal models in teaching and research. This was evidenced in $95.5 \%(43 / 45)$ of freshmen and $72.7 \%(32 / 44)$ of 
students of veterinary medicine, and $85 \%(34 / 40)$ of freshmen and $69.7 \%$ (23/33) of students of biological sciences. Such ignorance confirms that perhaps many student respondents are favourable to the use of animal models in teaching, signalling that educators and UENP-CLM researchers should be more attentive, including the guidelines of Federal Law 11.794.

Tréz (2000) reported that $68.3 \%$ of students surveyed in biology, medicine, nursing, nutrition, and pharmacy courses at the Federal University of Santa Catarina (UFSC, in Portuguese) favoured the use of substitute alternative methods in the university, whenever possible. Feijó et al. (2008) found the same opinion in $61.4 \%$ of students of biological sciences at PUCRS. Danielski et al. (2011) reported, however, that $92 \%$ of students of Medicine and $40.3 \%$ of biological sciences at UFRGS participate in classes in the university at graduation that use substitute methods. Of these, $62 \%$ of students of medicine and $61.6 \%$ of biological sciences believed that these methods could not always replace the use of animals.

Despite the bioethics or ethics applied to life, it was found that at UENP-CLM only $40 \%(18 / 45)$ of freshmen and $20.4 \%(9 / 44)$ of senior students of veterinary medicine and $7.5 \%(3 / 40)$ of freshmen and $30.3 \%(10 / 33)$ of students of biological sciences had studied or discussed the subject at some point in the course, for a total of $24.7 \%(40 / 162)$ of respondents. The paucity of information related to bioethics, animal welfare and legislation in force in the country was noted, confirming what Tréz and Nakada (2008) reported. According to these authors, $80 \%$ of student respondents said, "teachers rarely or never promote reflections and discussions about the fact that animals are exploited in their practices".

Lima et al. (2008) found that $41.7 \%$ of students surveyed also had no guidance on bioethics and legislation over teaching activities. Similarly, Deguchi et al. (2012) reported that $45.5 \%$ of biology, veterinary medicine, medicine, and pharmacology students were also unaware of existing legislation, which according to Melgaço et al. (2011) makes it difficult to replace the animal model in animal experiments. Therefore, in the first year of the course, it is important to discuss these issues and alternative methods that are validated by CEUAs.

However, at UFRGS, $84 \%$ of medicine and $63.4 \%$ of biological sciences students said they had received information over the course on the use of animals in academic activities, and 90\% and 98\% of students of each course, respectively, believed that ethical principles should be applied to activities with animals (DANIELSKI et al., 2011).

In this research, $100 \%(45 / 45)$ of freshmen and $88.6 \%(39 / 44)$ of senior students of veterinary medicine and 92.5\% (37/40) of freshmen and 100\% (33/33) of senior students of biological sciences considered that it is important to periodically offer elective courses to address animal welfare and bioethics in the programme curriculum. At UENPCLM, a class entitled "Animal Welfare", with a workload of 45 hours, was presented to students only one time, but the results of this study showed that it is important to continuously offer the class to promote discussion and reflection on the content in question. Consequently, this will create the opportunity to re-sensitize students and to change the existing anthropocentric paradigm. Whereas $48 \%$ (48/73) and 84\% (84/89) of biological sciences and veterinary medicine students respectively considered the use of animals in academic activities important to achieve the proposed pedagogical ideals, only $34.2 \%(25 / 73)$ of academics of the biological sciences and approximately 5.7\% (5/89) of veterinary medicine expressed some concern about the animal models used, even if used ethically.

Danielski et al. (2011) reported that $68 \%$ of students of medicine and $90.3 \%$ of biological sciences at UFRGS approved inclusion of the subject "Science in Laboratory Animals" in the curriculum of biological and health courses. 
Particularly in veterinary medicine at UENPCLM, several practices with live animals are routinely conducted in the laboratory, hospital environment, field, experimentation, and in practice lessons of some disciplines; this is accepted and received positively by teachers and students. However, for some invasive practices or harmful approaches to animals and for the improvement of surgical skills, anatomical specimens that died as a result of disease or natural death are obtained from slaughterhouses. According to Balcombe (2000), these forms of animal use can be considered alternatives to "misuse" of animals in classes.

Several alternative methodologies are available to teachers, such as computer simulations (virtual dissection), 3D models, plastic corpses (surgical mannequins, surgical organ prototypes), videos, slides, graphics, and online presentations among others. These strategies avoid the use of live animal models and ethical controversies. Furthermore, research indicates that learning of anatomy and physiology is met and the academic gains can be equivalent or superior to a class with traditional dissection (BALCOMBE, 2000).

We found that in UENP-CLM's Biological Sciences course aspects related to animal use are more directed to research activities than teaching, and are designed for Bachelor degree qualification and training for elementary and secondary teaching, with additional training in pedagogic areas. For theoretical and practical study of sentient animals (vertebrate zoology) that concerns morphology, physiology, immunology, and anatomy, professors used multimedia resources (CD-ROMs and videos), books, and corpses preserved in formaldehyde, alternatives that replace the live animal model according to Balcombe (2000).

Few students of UENP-CLM's veterinary medicine and biological sciences programmes had insight into bioethics. In this context the lack of clarity in the distinction between ethical and unethical practices can lead to actions that violate the "3Rs" and Federal Law 11.794/08.
Therefore, professors and researchers-holders of knowledge - are essential parts in the process in the dissemination of bioethical principles and examples (LIMA et al., 2008). The inclusion of curricular subjects at the university such as "Animal Welfare" and "Bioethics" can create innovative strategies that allow conscious, responsible, sustainable, and humanistic learning (SILVA, 2011).

The results of this study showed, even among senior students, lack of ethical and legal guidelines governing the use of animals in teaching and scientific experiments. In addition, there is great resistance to replace this model. According to Silva (2011), programmes should probably periodically offer a class such as "Animal Welfare" that can further instigate, discuss, and reflect on the content in question, creating opportunities again to raise awareness of students and, perhaps, change the existing anthropocentric paradigm.

A sustainable and ethical development of teaching and research knowledge is as important as "the sensitivity and understanding of the suffering and needs of the animal; the attitude and good judgment in decision-making are essential" (FRAJBLAT et al., 2008). It is the university's responsibility to implement educational policies leading to the development of new efficient teaching and learning methods, ensuring animal welfare (PAIXÃO, 2008) and avoiding dangerous simplification of the teaching process by strictly emphasizing vivisection techniques.

In short, in higher education it is important to keep the curriculum disciplines that address bioethics and animal welfare and that provide extensive discussion and reflection on the subject. Also, the involvement of teachers is equally required to also address the issue in various disciplines of the programme when appropriate. Therefore, further improvement in animal models is expected, both in teaching and in research, and perfecting students'knowledge, whether freshman or senior students. Thus, sustainable and humanitarian development of higher education may be reflected in the formation of more sensitive and 
ethical professionals - these perspectives should be taken as a goal for national education.

This project was approved by UENP's Ethics Committee and was supported by National Research Committee (CNPq, in Portuguese) and the Araucaria Foundation.

\section{References}

BALCOMBE, J. The use of animals in higher education: problems, alternatives and recommendations. Washington, The Humane Society Press, 2000, 104 p.

BRASIL. Lei n ${ }^{\circ}$ 9.605, de 12 de fevereiro de 1998. Dispõe sobre as sanções penais e administrativas derivadas de condutas e atividades lesivas ao meio ambiente, e dá outras providências. Diário Oficial [da] União, Brasília, 12 feb. 1998. Seção 1, p. 1. Disponível em: <http://www. planalto.gov.br/ccivil_03/Leis/L9605.htm>. Acesso em: 2 feb. 2015.

Decreto $n^{\circ} 6.899$, de 15 de julho de 2009. Dispõe sobre a composição do Conselho Nacional de Controle de Experimentação Animal - CONCEA, estabelece as normas para o seu funcionamento e de sua Secretaria- Executiva, cria o Cadastro das Instituições de Uso Científico de Animais - CIUCA, mediante a regulamentação da Lei $\mathrm{n}^{\circ} 11.794$, de 8 de outubro de 2008, que dispõe sobre procedimentos para o uso científico de animais, e dá outras providências. Diário Oficial [da] União, Brasília, 15 jul. 2009. Seção 1, p. 2. Disponível em: <http://www.planalto.gov.br/ccivil_03/_ Ato2007-2010/2009/Decreto/D6899.htm>. Acesso em: 22 aug. 2014.

- Lei $n^{\circ} 11.794$, de 8 de outubro de 2008. Regulamenta o inciso VII do $\S 1^{\circ}$ do art. 225 da Constituição Federal, estabelecendo procedimentos para o uso científico de animais; revoga a Lei oㅡ 6.638 , de 8 de maio de 1979; e dá outras providências. Diário Oficial [da] União, Brasília, 9 oct. 2008. Seção 1, p. 1. Disponível em: <http://www.planalto.gov.br/ccivil_03/_ato20072010/2008/lei/111794.htm>. Acesso em: 22 aug. 2014.

DANIELSKI, J. C. R.; BARROS, D. M.; CARVALHO, F. A. H. O uso de animais pelo ensino e pela pesquisa: prós e contras. Revista Eletrônica de Comunicação, Informação e Inovação em Saúde, Rio de Janeiro, v. 5, n. 1, p. 72-84, 2011.

DEGUCHI, B. G.; MOLENTO, C. F.; SOUZA, C. E. The perception of students on the use of animals in higher education at the Federal University of Paraná, Southern Brazil. Alternatives to Laboratory Animals, Nottingham, v. 40, n. 2, p. 83-90, 2012.
FEIJÓ, A. G. S.; SANDERS, A.; CENTURIÃO, A. D.; RODRIGUES, G. S.; SCHWANKE, C. H. A. Análise de indicadores éticos do uso de animais na investigação científica e no ensino em uma amostra universitária na Área da Saúde e das Ciências Biológicas. Scientia Medica, Rio Grande do Sul, v. 18, n. 1, p. 10-19, 2008.

FRAJBLAT, M.; AMARAL, V. L. L.; RIVEIRA, E. A. B. Ciência em animais de laboratório. Ciência e Cultura, São Paulo, v. 60, n. 2, p. 44-46, 2008.

KNIGHT, A. Humane teaching methods demonstrate efficacy in veterinary education. REDVET - Revista Electrectrónica de Veterinária, Málaga, v. 9, n. 10, p. 1-30, 2008.

LIMA, K. E. C.; MAYER, M.; CARNEIRO-LEÃO, A. M.; VASCONCELOS, S. D. Conflito ou convergência? Percepções de professores e licenciandos sobre ética no uso de animais no ensino de zoologia. Investigações em Ensino de Ciências, Porto Alegre, v. 13, n. 3, p. 353-369, 2008.

MELGAÇO, I. C. P. P. S.; MEIRELLES, R. M. S. E.; CASTRO, H. C. O uso de animais nas disciplinas de Anatomia, Fisiologia, Imunologia e Zoologia e suas implicações éticas e legais durante a educação científica. Revista Electrónica de Enseñanza de Las Ciencias, Ourense, v. 10, n. 3, p. 499-515, 2011.

PAIXÃO, R. L. Métodos substitutivos ao uso de animais vivos no ensino: repensando o que aprendemos com os animais no ensino. Ciência Veterinária nos Trópicos, Recife, v. 11, p. 88-91, 2008. Suplemento 1.

RUSSELL, W. M. S.; BURCH, R. L. The principles of humane experimental technique. London: Methuen, $1959,238 \mathrm{p}$.

SILVA, P. F. Educação em bioética: desafios na formação de professores. Revista Biotéica, Brasília, v. 19, n. 1, p. 231-234, 2011.

TRÉZ, T. A. O uso de animais vertebrados como recurso didático na Universidade Federal de Santa Catarina: panoramas, alternativas e a educação ética. 2000. Trabalho de Conclusão de Curso. (Graduação em Medicina Veterinária) - Faculdade de Medicina Veterinária, Universidade Federal de Santa Catarina, Florianópolis, Santa Catarina, 2000.

TRÉZ, T. A.; NAKADA, J. I. L. Percepções acerca da experimentação animal como um indicador do paradigma antropocêntrico-especista entre professores e estudantes de ciências biológicas da UNIFAL-MG. Revista de Educação em Ciência e Tecnologia, Florianópolis, v. 1, n. 3, p. 3-28, 2008. 